\title{
Binding of LH and FSH to porcine granulosa cells during follicular maturation
}

\author{
R. Nakano, T. Akahori, K. Katayama and S. Tojo \\ Department of Obstetrics and Gynaecology, Kobe University School of Medicine, Kobe, Japan
}

\begin{abstract}
Summary. The uptake of ${ }^{125}$ I-labelled LH by equal numbers of granulosa cells from small, medium or large follicles was greater by cells from large follicles. In contrast, granulosa cells obtained from small follicles bound much more ${ }^{125} \mathrm{I}$-labelled FSH per cell than did cells obtained from medium and large follicles. Competition studies with unlabelled hormones indicated that porcine granulosa cells have specific receptors for LH and FSH. The addition of diethylstilboestrol enhanced the binding of ${ }^{125} \mathrm{I}$-labelled LH and inhibited the binding of ${ }^{125}$ I-labelled FSH to granulosa cells harvested from small and medium-sized follicles, but had no effect on those from large follicles.
\end{abstract}

\section{Introduction}

Previous studies have suggested that specific receptors with high affinity for human LH and HCG are present on granulosa cells harvested from pig follicles (Kammerman, Canfield, Kolena \& Channing, 1972; Channing \& Kammerman, 1973a). However, there is little information about the binding of FSH to granulosa cells: specific binding of iodinated FSH to rat granulosa cells has been demonstrated by autoradiographic techniques (Midgley, 1973; Presl, Pospisil, Figarova \& Krabec, 1974) and the numbers of specific FSH receptors on rat granulosa cells have been measured (Nimrod, Erickson \& Ryan, 1976).

The present report is of the specific binding of LH and FSH to porcine granulosa cells during follicular maturation.

\section{Materials and Methods}

Highly purified human LH (Lot No. 235014) and human FSH (Lot No. 235015) were purchased from Calbiochem, Inc., California.

Iodination of LH and FSH was carried out by the lactoperoxidase method described by Miyachi, Vaitukaitis, Nieschlag \& Lipsett (1972), which employed $2 \mu \mathrm{g} \mathrm{FSH,} 1 \mathrm{mCi}$-equivalent of Na ${ }^{125} \mathrm{I}$ and $10 \mathrm{ng}$ lactoperoxidase in $60 \mu \mathrm{l} 0.4 \mathrm{M}$-sodium acetate, $\mathrm{pH} 5 \cdot 6$. After incubation at room temperature for $30 \mathrm{~min}$, three separate portions of $10 \mathrm{ng} \mathrm{H}_{2} \mathrm{O}_{2}$ (in $5 \mu$ ) were added at 10-min intervals. The reaction was stopped by adding $0.5 \mathrm{ml} 0.05 \mathrm{M}$-dithiothreitol. The labelled hormone was separated from excess $\mathrm{Na}^{125} \mathrm{I}$ by gel filtration on a Bio-Gel P-60 column. The specific activity of the LH and FSH was consistently in the order of $40-60 \mu \mathrm{Ci} / \mu \mathrm{g}$. The labelled hormone was stored at $4^{\circ} \mathrm{C}$ in a $0.14 \mathrm{M}-\mathrm{NaCl}-0.01 \mathrm{M}$-sodium phosphate buffer, $\mathrm{pH} 7.4$, containing $0.5 \%$ bovine serum albumin and $5 \mu \mathrm{g}$ sodium ethylmercurithiosalicylate/ml. No change in binding activity was found after 4 weeks of storage.

Granulosa cells were collected as described by Channing (1970) by aspiration from small (1-2 $\mathrm{mm}$ ), medium (3-5 mm) and large (6-10 mm) follicles from 6-12-month-old pigs. The granulosa cells were centrifuged to separate them from follicular fluid, washed and resuspended in Medium 199. Samples of the cell suspension were taken for cell counting, after which the volume was adjusted with Medium 199 to give a final concentration of $5 \times 10^{6}$ cells $/ \mathrm{ml}$.

The granulosa cell suspensions $(500 \mu \mathrm{l})$ were pipetted into a $10 \times 75 \mathrm{~mm}$ test tube containing $50 \mu \mathrm{l}^{125} \mathrm{I}$-labelled LH or ${ }^{125} \mathrm{I}$-labelled FSH solution $\left(1 \times 10^{6} \mathrm{ct} / \mathrm{min}\right)$, in Medium 199 . The tubes were incubated for 30,60 and $120 \mathrm{~min}$ at $37^{\circ} \mathrm{C}$ in a shaking incubator and then centrifuged at $2500 \mathrm{~g}$ for 10 min at $4^{\circ} \mathrm{C}$. The supernatant was removed by suction and the cells resuspended and washed three 
times with $1 \mathrm{ml}$ Medium 199. The tubes containing the pellets of washed granulosa cells were then counted in an automatic gamma counter. All radioactivities were corrected for minor non-specific binding of iodinated hormones to glass tubes and the incubations were performed in triplicate.

To investigate competition with unlabelled hormone, various doses of LH (Calbiochem LH or LER 960) or FSH (Calbiochem FSH or LER 1366) were added and the effects of unlabelled LH and FSH on the binding of the labelled hormones to granulosa cells from medium-sized follicles were plotted on a logarithm-logit paper.

To detect the effect of oestrogen on the binding of LH and FSH, 10-100 $\mu \mathrm{g}$ diethylstilboestrol (Nutritional Biochemicals, Corp., Cleveland, Ohio) were added to the tubes containing $500 \mu 1$ granulosa cell suspension. The tubes were incubated for $120 \mathrm{~min}$ at $37^{\circ} \mathrm{C}$ in a shaking incubator. After centrifugation the supernatant was removed by suction. The cells were resuspended in Medium 199 and the binding of ${ }^{125} \mathrm{I}$-labelled LH and FSH was tested as described.

\section{Results}

The appearances of haematoxylin and eosin stained smears of the granulosa cells obtained from small, medium and large follicles did not differ significantly. The mean ( \pm S.E.M.) cell diameters of the individual granulosa cells harvested from the three sizes of follicles were also similar (small, $13.6 \pm 0.6 \mu \mathrm{m}$; medium, $14.1 \pm 0.8 \mu \mathrm{m}$; large, $13.9 \pm 0.6 \mu \mathrm{m})$.

Incubation of granulosa cells from the three types of follicles resulted in a significant amount of labelled hormone being bound. The binding increased gradually from 30 to $120 \mathrm{~min}$. The granulosa cells collected from large follicles bound much more ${ }^{125}$ I-labelled LH per cell than did cells collected from small or medium-sized follicles $(P<0.01)$ (Table 1). In contrast, the granulosa cells from small follicles bound much more ${ }^{125} \mathrm{I}$-labelled FSH per cell than did cells obtained from medium or largesized follicles $(P<0.01$; Table 1$)$. These differences in hormone binding cannot be attributed to differences in cell size, because the diameters of the granulosa cells were similar, whatever their source.

Table 1. The binding of ${ }^{125} \mathrm{I}$-labelled $\mathrm{LH}$ and ${ }^{125} \mathrm{I}$-labelled FSH to porcine granulosa cells harvested from follicles of different sizes

\begin{tabular}{|c|c|c|c|c|c|c|}
\hline & \multicolumn{6}{|c|}{ Time of incubation (min) } \\
\hline & \multicolumn{3}{|c|}{ LH binding } & \multicolumn{3}{|c|}{ FSH binding } \\
\hline & 30 & 60 & 120 & 30 & 60 & 120 \\
\hline Small & $7533 \pm 521$ & $9122 \pm 632$ & $9522 \pm 531$ & $1428 \pm 258$ & $20833 \pm 461$ & $28008 \pm 642$ \\
\hline Medium & $15521 \pm 732$ & $18103 \pm 1212$ & $30122 \pm 822$ & $5677 \pm 270$ & $8211 \pm 573$ & $10541 \pm 362$ \\
\hline Large & $55012 \pm 821$ & $65502 \pm 1252$ & $72306 \pm 1921$ & $5103 \pm 167$ & $6512 \pm 296$ & $9147 \pm 249$ \\
\hline
\end{tabular}

Values are mean \pm S.E.M. (ct $/ \mathrm{min} / 5 \times 10^{6}$ cells).

Unlabelled LH competed with ${ }^{125}$ I-labelled LH for binding sites of granulosa cells obtained from medium-sized follicles in a graded manner, whereas unlabelled FSH did not (Text-fig. 1a). Unlabelled FSH also inhibited the binding of ${ }^{125}$ I-labelled FSH to granulosa cells in a graded manner, but unlabelled LH did not (Text-fig. 1b).

Table 2. The effect of diethylstilboestrol on the binding of ${ }^{125} \mathrm{I}$-labelled $\mathrm{LH}$ and FSH to porcine granulosa cells from medium-sized follicles

\begin{tabular}{lccccc}
\hline & \multicolumn{5}{c}{ Dose of diethylstilboestrol $(\mu \mathrm{g})$} \\
\cline { 2 - 6 } & 0 & 10 & 20 & 50 & 100 \\
\hline LH binding & $4012 \pm 186$ & $4185 \pm 116$ & $4514 \pm 523$ & $7721 \pm 162$ & $7572 \pm 193$ \\
FSH binding & $9075 \pm 262$ & $7682 \pm 103$ & $3425 \pm 292$ & $1382 \pm 76$ & $1508 \pm 173$ \\
\hline
\end{tabular}

Values are mean \pm S.E.M. $\left(\mathrm{ct} / \mathrm{min} / 5 \times 10^{6}\right.$ cells $)$ 
Table 3. Effect of $50 \mu \mathrm{g}$ diethylstilboestrol on the binding of ${ }^{125} \mathrm{I}$-labelled $\mathrm{LH}$ and FSH to porcine granulosa cells from follicles of different sizes

\begin{tabular}{|c|c|c|}
\hline Follicles & LH binding & FSH binding \\
\hline \multicolumn{3}{|l|}{ Small } \\
\hline $\begin{array}{l}\text { Control } \\
\text { Experimental }\end{array}$ & $\begin{array}{l}1482 \pm 121 \\
5196 \pm 276\end{array}$ & $\begin{array}{l}9692 \pm 278 \\
4442 \pm 176\end{array}$ \\
\hline \multicolumn{3}{|l|}{ Medium } \\
\hline $\begin{array}{l}\text { Control } \\
\text { Experimental }\end{array}$ & $\begin{array}{l}4463 \pm 305 \\
7697 \pm 174\end{array}$ & $\begin{array}{l}8476 \pm 682 \\
4822 \pm 186\end{array}$ \\
\hline \multicolumn{3}{|l|}{ Large } \\
\hline $\begin{array}{l}\text { Control } \\
\text { Experimental }\end{array}$ & $\begin{array}{l}6582 \pm 282 \\
7012 \pm 191\end{array}$ & $\begin{array}{l}5982 \pm 286 \\
6142 \pm 212\end{array}$ \\
\hline
\end{tabular}

Values are mean \pm S.E.M. (ct $/ \mathrm{min} / 5 \times 10^{6}$ cells).

The effects of adding diethylstilboestrol to the incubation of granulosa cells from medium-sized pig follicles with labelled hormones are shown in Table 2. The two high doses caused a significant increase in LH binding $(P<0.01)$. When $50 \mu \mathrm{g}$ diethylstilboestrol were added to incubations of granulosa cells (Table 3), the binding of labelled LH was increased with cells from small and mediumsized follicles but was not affected with cells from large follicles $(P<0.01)$. FSH binding was decreased with cells from small and medium-sized follicles $(P<0.01)$.

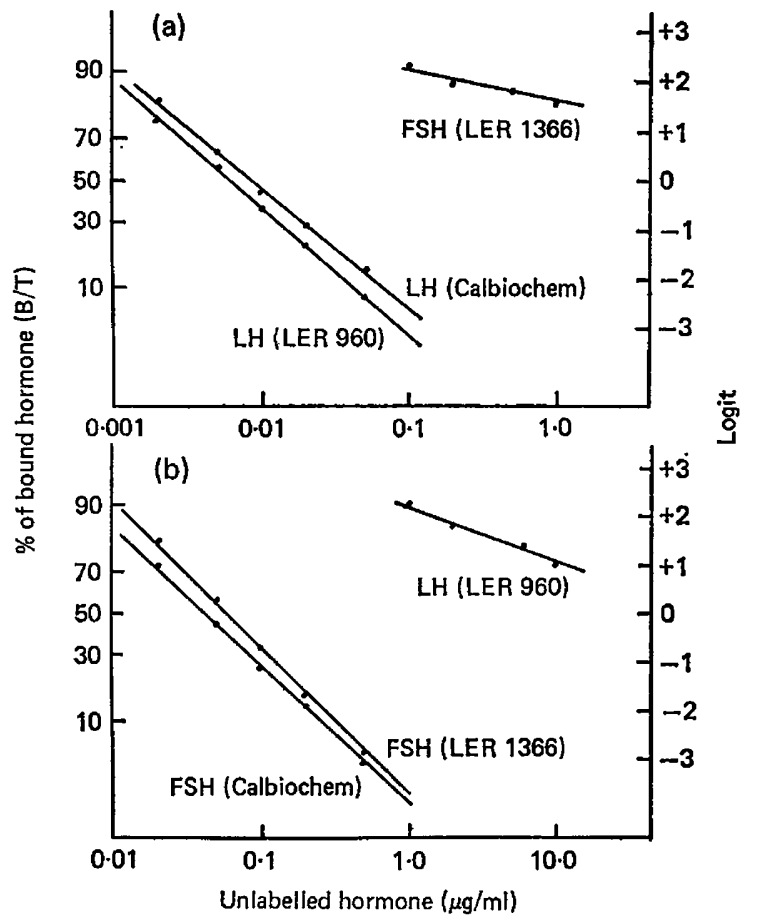

Text-fig. 1. The effects of LH and FSH on the binding of (a) ${ }^{125}$ I-labelled LH and (b) ${ }^{125}$ I-labelled FSH to porcine granulosa cells from medium-sized follicles.

\section{Discussion}

Specific receptors with high affinity for human LH and HCG have been demonstrated in a variety of testis and ovary preparations (Lee \& Ryan, 1973; Dufau, Charreau \& Catt, 1973; Hanour \& Saxena, 1974). Granulosa cells harvested from porcine follicles have been particularly useful in studying 
gonadotrophin-receptor interactions (Kammerman et al., 1972; Channing \& Kammerman, 1973a) because they represent a uniform population of intact cells of a single type, obtainable without excessive trauma from a target organ which contains many types of cells. These granulosa cells have been shown to bind specifically radioiodinated HCG and probably to have the same receptor for both HCG and LH (Kammerman et al., 1972; Channing \& Kammerman, 1973b).

The present finding that granulosa cells harvested from large follicles bound much more ${ }^{125} \mathrm{I}$ labelled LH per cell than did cells harvested from small or medium-sized follicles, although the cells themselves are of the same size, is consistent with previous reports (Channing \& Kammerman, 1973a). This increased gonadotrophin binding may explain why $\mathrm{LH}$ is capable of stimulating cyclic AMP production and progesterone only in the mature follicle cell (Channing \& Kammerman, 1973a). The increased binding represents an increase in the number of binding sites on granulosa cells during follicle maturation (Kammerman \& Ross, 1975).

Our study has shown that porcine granulosa cells also have binding sites for FSH, and cells collected from small follicles bound much more ${ }^{125} \mathrm{I}$-labelled FSH per cell than did cells from medium or large follicles. The competition studies with unlabelled hormones revealed that porcine granulosa cells have specific receptors for LH and FSH, and the binding characteristics of labelled FSH and LH to the granulosa cells from the three follicle types are in sharp contrast.

The concentration of oestrogen in follicular fluid is known to increase during follicular maturation (Sanyal, Berger, Thompson, Taymor \& Horne, 1974; McNatty, Hunter, McNeilly \& Sawers, 1975). Oestrogen has also been reported to stimulate synthesis of progesterone by porcine granulosa cells in tissue culture (Goldenberg, Bridson \& Kohler, 1972). Our experiments with diethylstilboestrol showed enhanced binding of labelled LH and suppressed binding of labelled FSH to granulosa cells harvested from small and medium-sized pig follicles. In contrast, Richards (1975) and Richards \& Midgley (1976) found that oestrogen stimulated FSH binding, but not LH binding, in rats. This difference might be a real specific difference or due to variation in the experimental systems.

From these studies, it is evident that there are two specific receptors for LH and FSH on porcine granulosa cells. Furthermore, there is a marked difference between the binding of ${ }^{125}$ I-labelled LH and ${ }^{125}$ I-labelled FSH to granulosa cells collected from the three sizes of follicle. Although the reason for this marked difference, other than degrees of follicular maturation, is not evident, our results suggest that oestrogen might play an important role in the binding of LH and FSH to granulosa cells.

We thank the National Pituitary Agency and the Endocrinology Study Section of the NIAMDD for the generous supply of human pituitary gonadotrophins, LER 960 and LER 1366.

\section{References}

Channing, C.P. (1970) Effect of stage of the estrous cycle and gonadotrophins upon luteinization of porcine granulosa cells in culture. Endocrinology 87, 156-164.

Channing, C.P. \& Kammerman, S. (1973a) Characteristics of gonadotropin receptors of porcine granulosa cells during follicle maturation. Endocrinology 92, 531-540.

Channing, C.P. \& Kammerman, S. (1973b) Effects of hCG, asialo-hCG and the subunits of hCG upon luteinization of monkey granulosa cell cultures. Endocrinology 93, 1035-1043.

Dufau, M.L., Charreau, E.H. \& CatT, K.J. (1973) Characteristics of a soluble gonadotropin receptor from rat testis. J. biol. Chem. 248, 6973-6982.

Goldenberg, R.L., Bridson, W.E. \& Kohler, P.O. (1972) Estrogen stimulation of progesterone synthesis by porcine granulosa cell in culture. Biochem. Biophys. Res. Commun. 48, 101-107.
HANOUR, F. \& SAXENA, B.B. (1974) Characterization and solubilization of gonadotropin receptor of bovine corpus luteum. J. biol. Chem. 249, 2195-2205.

Kammerman, S., Canfield, R.E., Kolena, J. \& CHANNING, C.P. (1972) The binding of iodinated hCG to porcine granulosa cells. Endocrinology 91, 65-74.

Kammerman, S. \& Ross, J. (1975) Increase in numbers of gonadotropin receptors on granulosa cells during follicle maturation. J. clin. Endocr. Metab. 41, 546550.

LEE, C.Y. \& RYAN, R.J. (1973) Interaction of ovarian receptors with human luteinizing hormone and human chorionic gonadotropin. Biochemistry, N.Y. 12, 4609-4615.

McNatTY, K.P., Hunter, W.H., McNeilly, A.S. \& SAWERS, R.S. (1975) Changes in the concentration of pituitary and steroid hormones in the follicular fluid of human Graafian follicles throughout the menstrual cycle. J. Endocr. 64, 555-571. 
Midgley, A.R., JR (1973) Autoradiographic analysis of gonadotropin binding to rat ovarian tissue sections. Adv. exp. Med. Biol. 36, 365-378.

MiYachi, Y., Vaitukaitis, J.L., Nieschlag, E. \& LIPSETT, M.P. (1972) Enzymatic iodination of gonadotropins. J. clin. Endocr. Metab. 34, 2328.

NimRod, A., Erickson, G.F. \& Ryan, K.J. (1976) A specific receptor in rat granulosa cells: properties of binding in vitro. Endocrinology 98, 56-64.

Presl, J., Pospisil, J., Figarova, V. \& Krabec, Z. (1974) Changes in iodine-125 labelled hFSH (human pituitary FSH) uptake during ovarian follicle maturation in rats. Endocr. exp. 8, 2-8.
RICHARDS, J.S. (1975) Estradiol receptor content in rat granulosa cells during follicular development: modification by estradiol and gonadotropins. Endocrinology 97, 1174-1184.

Richards, J.S. \& MidgleY, A.R., JR (1976) Protein hormone action: a key to understanding ovarian follicular and luteal cell development. Biol. Reprod. 14, 82-94.

Sanyal, M.K., Berger, M.J., Thompson, I.E., TAYMOR, M.L. \& HORNe, H.W. (1974) Development of Graafian follicles in adult human ovary. I. Correlation of estrogen and progesterone concentration in antral fluid with growth of follicles. J. clin. Endocr. Metab. 38, 828-835.

Received 2 September 1976 